\title{
Scandinavian heirlooms for wellbeing
}

\author{
S. Friis Pedersen ${ }^{a}$ \\ NORSOK, Norwegian Centre for Organic Agriculture, Tingvoll, Norway.
}

\begin{abstract}
Seed availability in general has narrowed tenfold down, comparing seed catalogs in a century perspective. Not only the supply offered by catalogs has minimized; the seed supply chain has been monopolized to a few giant companies globally. Organic horticulture depends on this market supply but could also take more advantage on local seed exchange of open pollinated varieties. Open pollinated varieties, often heirlooms, offer the gardener an opportunity to be self-sufficient with viable, locally adapted seeds. Heirlooms are, if not susceptible to pathogens, often quite suitable and adaptive to organic small-scale cultivation. They will yield reasonable even though fertilization is not abundant, and they will yield longer per season. The recent adjustment of EU regulation for organic production will possibly open for use of noncertified organic seed like heirlooms. The objective of this work was to examine if seedsavers-organizations may provide site-specific and reliable seeds for organic horticulture. The scope was limited to a Scandinavian case study where a formal and an informal seed market exists side by side. Seed saving and seed exchange have a long tradition in Sweden, Denmark and Norway, often in organized networks. The Nordic Genetic Resource Centre (Nordgen) plays a prominent role providing and conserving Nordic heirlooms. Some heirlooms have even been reintroduced to national variety lists. Each of Scandinavian countries host at least one seed company providing only organic seeds but very dedicated to heirlooms. In all Scandinavian countries, there is an increasing interest in heirloom varieties. This might lead to an increased interest for organic gardening, supporting the well-being of the environment and the population.
\end{abstract}

Keywords: seed exchange, seed biodiversity, seed market, participatory plant breeding

\section{INTRODUCTION}

Seed availability and diversity in crop plants have decreased. Seed supply chains have been monopolized to a few giant companies globally. FAO found reduced agro-biodiversity alarmingly low already in 1997 when they estimated that $75 \%$ of global food consumption relied on only 12 plant species, while almost 7,000 plant species have been used in agriculture during human history (FAO, 1997). A follow-up on 113 countries showed that the number of countries with an official national program to protect plant genetic resources have increased from 52 to 80. Ex-situ conservation (in seed banks) has increased approximately $20 \%$ since 1997. In-situ conservation within on-farm management has become a highly useful additional method of conservation. The seeds are broadly disseminated, and knowledge about the crop management is actively maintained. The method has become of important evidence for science and holds high public awareness (FAO, 2010).

\section{Organic seed market}

The organic seed market covers at least 14 major key players globally mostly from the USA. Among the biggest seed distributors, one is the organization Seed Savers Exchange featuring heirlooms. Seed Saver Exchange is a non-profit community taking stewardship of more than 25,000 rare and heirloom varieties in the USA. They support and educate communities and individuals to take care of seed growing and sharing. Their seed types are divided in non-GMO, heirloom vegetables and organic vegetable seeds. The organic seed type follows the standards of USDA's National Organic Program (NOP). Heirlooms are defined by

aE-mail: susanne.friis.pedersen@norsok.no 
"seeds that have been saved and shared by generations of home gardeners" (Seedsavers, 2018).

Organic horticulture depends on this market supply but could also take more advantage on local seed exchange of open pollinated varieties. Open pollinated varieties, often heirlooms, offer the gardener an opportunity to be self-sufficient in viable, locally adapted seeds. Heirlooms are, if not susceptible to pathogens, often quite suitable and adaptive to organic small-scale cultivation. They will yield longer per season because they are less homogeneous genetically than for example $F_{1}$ hybrids. The recent adjustment of EU regulation for organic production could possibly open for use of non-certified organic seed such as heirlooms (European Commission, 2017). For the first time on national level in Norway, it is pronounced that there can be given dispensation for use of certified organic seed material if the grower prefers a certain variety which is worth conserve (Norwegian Food Safety Authority, 2018).

\section{Formal and informal seed market}

The market channels for seeds in general are divided in a formal market which are commercial or state-led sale and an informal market defined by non-profit seed exchange. In Europe and North America, the formal market covers 90\% while in many developing countries less than $10 \%$ of sown seeds are bought in a formal way. Networks with exchange of seeds are assumed to play an important role for rural well-being and food security in many developing countries (Coomes et al., 2015; Pautasso et al., 2013). Nevertheless, seeds connected to the formal market have traditionally been considered better quality than seeds appearing in the informal market without currency. Quality of seeds connected to health, vitality and purity is incorporated in the formal market and sellers must be approved seed distributors as well. Genetic characters and homogeneity are other quality aspects connected to seed business. These mentioned quality aspects can be difficult to apply on small-scale seed exchange among non-professional enthusiasts. The formal organic seed market in Europe is small and developing effort minimal (Döring et al., 2012). Breeding techniques at a lower level than the cell unit is not in compliance with organic principles, because the intrinsic value of the plant is disturbed as stated in IFOAM position paper (IFOAM, 2016). Therefore, the European Consortium for Organic Plant Breeding, ECO PB, and the European Association for Research on Plant Breeding, EUCARPIA, have been formed and have initialized some projects in the field of organic and open pollinated old varieties.

\section{Seed legislation}

At a glance biodiversity legislation started out in 1992 with world society commitment to conservation of biodiversity and recognition that sustainable development must be implemented, all formulated in the international Convention on Biodiversity, CBD. The CBD was in 2004 followed up by Multilateral System for Plant Genetic Resources, MLS, where The Plant Treaty covered trade with 64 food and forage plant species. The Plant Treaty is ratified by 140 countries and members are underway with a collective understanding of norms for Farmers' Rights to save, exchange and sell seed and plant propagating material. Farmers' Rights are formulated in article 9 and enables growers to deal their product and rewards them for their contribution to agrobiodiversity (Anonymous, 2017).

International Union for Protection of New Varieties of Plants (UPOV) gives credit to breeders and companies recovering their costs in plant breeding of new varieties (UPOV, 2018). It was formed in 1961 and covers 75 members (both countries and organizations) per 2017. UPOV is the responsible institution to recognize a new variety by "DUS-test" confirming the Distinctness, Uniformity and Stability of the seed material.

\section{Motive and purpose}

Heirlooms varieties originates from a time before the UPOV regulation and if they had been on the formal market earlier than 1961 then DUS-test is not required for them. But it is essential to note that not all heirlooms are recognized as variety, some is exchanged only recognized as landrace or a certain line of a variety. Then one may decide which motive for the production is the most important. It could, as mentioned for small-scale producers, be 
caretaking for agro-biodiversity more than food security and yield.

This paper presents the status of organic seed market in Scandinavia. The paper discusses how to meet both formal market legislation and people's engagement in seed saving. Scandinavian heirlooms could hereby cover goals for agro-biodiversity conservation, resilience and wellbeing. Wellbeing is interpreted as: Save environmentally right cultivation of site-specific vegetables, that might taste great and be resistant to pests and diseases.

The objective of this paper was also to examine the role of seed-savers-organizations in the Scandinavian market and society. Seed-savers-organizations seem to be upcoming important actors in the organic seed market. The focus is seeds of vegetables historically grown in the region. This is mostly cabbage, root crops and peas.

\section{MATERIAL AND METHODS}

This paper is a product of seminars and workshops conducted by the Norwegian Plant Diversity Network during a period from 2011 to 2017, where the author has been actively involved. Literature and market survey have been used to collect specific information as required.

\section{RESULTS}

\section{Overview}

Scandinavia holds a long tradition for international collaboration, also in seed conservation, The Svalbard Global Seed Vault is a corporation between the Norwegian Ministry of Agriculture and Food; Global Crop Diversity Trust and Nordic Genetic Resource Centre (NordGen). The Nordic countries hereby works together for ex-situ conserving of Nordic genetic resources. The Kalmar declaration from 2003 lines out a common right to access these resources (Anonymous, 2003). With respect to vegetable varieties, this includes 35 varieties of white cabbages, Brassica oleracea var. capitata f. alba, 27 of turnips, Brassica rapa ssp. rapa, 10 of garden peas Pisum sativum L. ssp. sativum and 8 of beans, Phaseolus vulgaris (Rasmussen M., pers. commun., 2018).

Beside official gene banks one will find community seed banks, seed libraries, seed swaping events and organizing of seed savers (Andersen et al., 2018; IFOAM EU GROUP, 2013). Seed saving and seed exchange has a long tradition, especially in Sweden where it has been organized in a network since 1982 (Sesam, 2018). Denmark formed their network "Frøsamlerne" (Eng.: seed collectors) in 1987 (Foreningen Froesamlerne, 2018) and Norway established Norwegian Seed Savers in 2016 (NSS, 2018). The number of individuals in these organizations is approximately 1200 in Sesam, 900 in Frøsamlerne and 400 in Norwegian Seed Savers. Seed catalogs from these organizations offer 1000 seed varieties in Sweden, 600 in Denmark and the same amount in Norway.

\section{Data}

Some varieties in the catalogs even have a transnational Scandinavian story. The variety 'Pea from Marie' of garden pea is originally from Hurum in Norway but traveled in 1893 with a woman named Marie to her new home and family in south of Zealand in Denmark. Continuously caretaking in the family of this pea makes it possible to offer seeds for the present both in Denmark and Norway (Foreningen Froesamlerne, 2015). 'Pea from Marie' is also stored in the Global Seed Vault at Svalbard (SESTO, 2018a).

Another garden pea variety 'Early English Saber' which is stored in the Svalbard vault by accessions from both Denmark, Norway and Sweden (SESTO, 2018b) has recently been reintroduced to the national variety list in Norway (Solhatt, 2018). It was brought to Norway in the late 1800s and lines from Norwegian selection in the early 1900s showed as much as 10 peas in the pod (Bratberg, pers. commun.).

Cabbages and roots are in a Danish project investigated for health benefits related to higher content of bitterness like it was common before modern breeding and change of taste preferences to the sweeter. It seems like content of bitterness plays both a prophylactic and a curative effect (Anonymous, 2018). Several varieties are brought out from ex-situ storage and 
reintroduced into hospitalized or healthy people. Seed savers are involved (Windfeld L. pers. commun.).

Seed saving leading to form community seed banks are the subject for the project DIVERSIFOOD funded by EU's Horizon 2020 Programme (DIVERSIFOOD, 2018). Some bridging between in-formal and formal market appears and the monopolized seed markets becomes more diversified again. To prove this statement Table 1 shows how the formal markets in Scandinavian countries include heirlooms.

Table 1. Examples of Scandinavian seed companies including heirlooms and organic seeds.

\begin{tabular}{lccc}
\hline Company name & Organic certified seeds & Heirlooms & Conventional seeds \\
\hline Denmark & X $50^{\mathrm{a}}$ & $\mathrm{X}$ & $\mathrm{X}$ \\
Froedepotet & $\mathrm{X}$ & $\mathrm{X} 500$ varieties & \\
$\begin{array}{l}\text { Fuglebjerggaard } \\
\text { Solsikken }\end{array}$ & $\mathrm{X} 280$ varieties & & \\
Urtegartneriet & $\mathrm{X} 350$ varieties & & \\
\hline Norway & $\mathrm{X}$ & & $\mathrm{X}$ \\
Botanisk verden/Zimtrade & $\mathrm{X}$ & $\mathrm{X}$ & $\mathrm{X}$ \\
Efferus & $\mathrm{X}$ & & \\
Garden Living & $\mathrm{X}$ & & \\
Gartnerbutikken & $\mathrm{X}$ & $\mathrm{X}$ & \\
Greentrend & $\mathrm{X}$ & $\mathrm{X}$ & $\mathrm{X}$ \\
$\begin{array}{l}\text { Plukkselv } \\
\text { Solhatt }\end{array}$ & $\mathrm{X}$ & $\mathrm{X}$ & $\mathrm{X}$ \\
\hline Sweden & $\mathrm{X}$ & $\mathrm{X}$ & 200 varieties $^{\mathrm{b}}$ \\
Runåbergs fröer, total 675 & $\mathrm{X}$ & & $\mathrm{X}$ \\
varieties & $\mathrm{X}$ & & \\
Impecta, total 2000 varieties & $\mathrm{X}$ & $\mathrm{X}$ & \\
Lindbloms & & & \\
Rara Växter & & & \\
Froer.nu & & & \\
ECONOVA (Weibulls and & & & \\
Hammenhögs) & & & \\
\hline
\end{tabular}

aHerbs also included, bNever stained.

\section{DISCUSSION}

\section{Overview}

The quantity of diverse varieties offered by seed-saving-organizations seems equal to the offering by companies, even though not all companies write their amount. The heirlooms have proved their quality according to taste and resilience during several human generations. Still one may consider if the seed is sound and viable for organic producers. No guarantees are given by the seed provider like in the formal market. Anyway, it seems like some organic producers with local sale and their consumers favors private relationships and stories related to the variety rather than trustfully tested seed from the formal market. Indeed, this is one stream in the organic movement, where another stream would be having the seed certified organic right from the start. Breeding companies, already invested energy and money in organic breeding, would of course, promote this stream. Scientists, already invested energy and time in breeding, would probably do the same. At the last BIOFACH trade fair there was a seminar promoting the statement that organic certified seeds is a must (Biofach, 2018). The discussion would consequently be if it is to the organic producer or the regulation to choose. The discussion would as well be if local seed markets can follow up demand on organic seeds. Several researchers have stated that in the future, local food systems will be more important 
than global ones (Rahmann et al., 2016). The question is then if future organic adjustments would require only certified organic seeds or if heirlooms could be included without further bureaucracy for the producer. A possible scenario could be that including heirlooms in seeds for organic horticulture could lead to recruitment of more organic producers.

\section{Data}

Trends in the Scandinavian seed market indicates that other criteria than the ones the formal market sticks to, like purity, viability and vitality comes up. One may consider if upcoming quality aspects like conservation should be reasonably added. It is still of great importance that the authorities protects the buyer defining these standards for good seed quality. Nevertheless, the informal seed exchange, often without currency involved, adds meaning for many people concerned about decrease of biodiversity. The organic sector which aims for high biodiversity should rather include this trend than exclude it.

\section{CONCLUSIONS}

The following conclusions can be drawn from the study:

- The organic seed market is spread on more hands than conventional market even though it is a small market;

- The global monopolization of seed market is not so visible or outspoken in Scandinavia;

- Each of the Scandinavian countries hosts at least one seed company providing only organic seeds but very dedicated to heirlooms;

- In these countries there is a profound interest in heirlooms. This might as well lead to an increased interest for organic gardening;

- There is a potential for more heirloom varieties meeting the legislation and formal market like the presented cases;

- There is potential for more research how the content of bitterness in heirlooms could prevent or alleviate human chronic diseases;

- Seed savers organizations are upcoming important actors in the organic seed market and society. The quantity of varieties for sale is equal to formal companies;

- Seed savers organizations could provide wellbeing for the environment and population.

\section{ACKNOWLEDGEMENTS}

The author wants to acknowledge L. Windfeldt, Froesamlerne, for bringing the Scandinavian organizations together at the Slow Food event 28.-29. of April 2018. Thanks to L. Ansebo, Sesam, for positive contribution and boardmembers at NSS for inspiring work. Thanks to G. L. Serikstad and A. K. Loes, NORSOK for assistance with this paper.

\section{Literature cited}

Andersen, R., Shrestha, P., Otieno, G., Nishikawa, Y., Kasasa, P., Mushita, A., et al. (2018). Community seed bankssharing experiences from north and south. Report from a side event held 1. November 2017 during the $7^{\text {th }}$ session of the governing body of International Treaty on Plant Genetic Resources for Food and Agriculture in Kigali (Rwanda), pp.44.

Anonymous. (2003). www.norden.org/da/nordisk-ministerraad/ministerraad/nordisk-ministerraad-for-fiskerihavbrug-jordbrug-levnedsmidler-og-skovbrug-mr-fjls/deklarationer-erklaeringer-ogbeslutninger/kalmardeklarationen

Anonymous. (2017). Farmers' Rights. Diversifood Innovation Factsheet \# 9. www.diversifood.eu.

Anonymous. (2018). www. bittersund.dk/

Biofach (2018). www.biofach.de/en/news/press-releases/right-from-the-start-8kybjb5yyc_pireport

Coomes, O.T., McGuire, S.J., Garine, E., et al. (2015). Farmer seed networks make a limited contribution to agriculture? Four common misconceptions. Food Policy 56, 41-50.

DIVERSIFOOD. (2018) www.diversifood.eu 
Döring, T.F., Bocci, R., Hitchings, R., Howlett, S., Lammerts van Bueren, E.T., Pautasso, M., Raaijmakers, M., Rey, F., Stubsgaard, A., Weinhappel, M., et al. (2012). The organic seed regulations framework in Europe: current status and recommendations for future development. Org. Agric. 2012 (2), 173-183 https://doi.org/10.1007/s13165012-0034-7.

European Commission. (2017). The New Organic Regulation. European Commission-Fact Sheet http://europa.eu/rapid/press-release_MEMO-17-4686_en.htm (accessed February 20, 2018).

FAO. (1997) The state of the Wolds Plant Genetic Resources for Food and Agriculture (Rome, Italy), pp.540. http://www.fao.org/3/a-w7324e.pdf

FAO. (2010). The Second Rep. on the State of the World's Plant Genetic Resources for Food and Agriculture. Rome pp. 399. ISBN 978-92-5-106534-1 http://www.fao.org/docrep/013/i1500e/i1500e.pdf

Foreningen Froesamlerne. (2018). www.froesamlerne.dk

Foreningen Froesamlerne. (2015). Aerter og bønner - genopdagelse af 28 gamle danske sorter. pp.130.

IFOAM. (2016). Genetic Engineering and Genetically Modified Organisms. Position paper. pp.12. https://www.ifoam.bio/sites/default/files/position_genetic_engineering_and_gmos.pdf

IFOAM EU GROUP (2013). Toward More Crop Diversity-Adapting Market Rules for Future Food Security, Biodiversity and Food Culture. Position paper. pp.14.

Norwegian Food Safety Authority. (2018) Regelverksveileder Økologisk landbruk. Utfyllende informasjon om regelverket for økologisk landbruksproduksjon. Versjon14. Februar 2018 p.23. https://www.mattilsynet.no/om_mattilsynet/gjeldende_regelverk/veiledere/veileder_okologisk_landbruk.2651 /binary/Veileder\%20\%C3\%B8kologisk\%20landbruk

NSS. (2018) www.norwegianseedsavers.no

Pautasso, M., Aistara, G., Barnaud, A., Caillon, S., Clouvel, P., Coomes, O.T., Delêtre, M., Demeulenaere, E., De Santis, P., Döring, T., et al. (2013). Seed exchange networks for agrobiodiversity conservation. A review. Agron. Sustain. Dev. 33 (1), 151-175 https://doi.org/10.1007/s13593-012-0089-6.

Rahmann, G., Ardakani, M.R., Bárberi, P., et al. (2016). Organic Agriculture 3.0 is innovation with research. Org. Agric. 2016 (7), 169.

Seedsavers. (2018). www.seedsavers.org

Sesam. (2018). www.foreningensesam.se

SESTO. (2018a). https://sesto.nordgen.org/sesto/index.php?scp=ngb\&thm=sesto\&lev=acc\&rec=48780

SESTO.

https://sesto.nordgen.org/sesto/index.php?scp=ngb\&thm=sesto\&lev=tax\&rec=23310\&lst=acc\&let=\&ord $=$ accnam\&filter $=\& \mathrm{cnt}=50 \& \mathrm{stp}=25$

Solhatt (2018). www. solhatt.no/butikk/sukkerert-engelsk-sabel.

UPOV Union for Protection of New Varieties of Plants. (2018). www.upov.int/portal/index.html.en 